\title{
Creation of glyphosate-resistant Brassica napus L. plants expressing DesC desaturase of cyanobacterium Synechococcus vulcanus
}

\author{
L. O. Sakhno ${ }^{1}$, I. M. Gerasymenko' ${ }^{1}$ I. K. Komarnitsskii', \\ Y. V. Sheludko ${ }^{1}$, I. V. Goldenkova-Pavlova ${ }^{2}$ \\ ${ }^{1}$ Institute of Cell Biology and Genetic Engineering NAS of Ukraine \\ 148, Akademika Zabolotnoho Str., Kyiv, Ukraine, 03680 \\ ${ }^{2}$ N. I. Vavilov Institute of General Genetics RAS \\ 3, Gubkina Str., Moscow, Russian Federarion, 119991 \\ sakhno@icbge.org.ua
}

\begin{abstract}
Aim. Creation of glyphosate-resistant canola plants expressing bifunctional hybrid desC::licBM3 gene. In the hybrid gene the sequence of DesC desaturase of cyanobacterium $S$. vulcanus without plastid targeting was fused with the sequence of thermostable lichenase reporter LicBM3 gene. Methods. Agrobacterium tumefaciensmediated transformation, PCR, quantitative and qualitative determination of lichenase activity, genetic analysis. Results. Transgenic canola plants, carring the enolpyruvat shikimat phosphate syntase gene (epsps), conferring on plants resistance to phosphonomethyl glycine herbicides (Roundup), as well as the desC::licBM3 gene, were selected. The presence of transgenes was confimed by multiplex PCR. The epsps gene expression in canola was shown at the transcription level, during in vitro growth and after greenhouse herbicide treatment. Activity of the licBM3 gene product as a part of hybrid protein allowed quantitative and qualiative estimation of the desaturase gene expression. Inheritance of heterologous genes and their expression in the first generation were investigated. Conclusions. Transgenic canola plants were obtained, the presence of trangenes in plant genome was proved and expression of the target genes was detected.
\end{abstract}

Keywords: Brassica napus, desC, epsps, licBM3, lichenase.

Introduction. Due to climate changes, the plant resistance to stress factors of various origin, including low temperatures and phytopathogens, becomes of great importance.

One of the plant adaptive mechanisms to cold is an increase in the unsaturation of fatty acid residues in cellular membranes, sustaining the required membrane fluidity at low temperatures [1]. An important role in this process is attributed to fatty acid desaturases, catalyzing the transformation of a single bond between carbon atoms in acyl chains (C-C) into the double bond $(\mathrm{C}=\mathrm{C})$. According to the current data, the synthesis of $\Delta 9$-mono-unsaturated fatty acids in higher plants

(C) Institute of Molecular Biology and Genetics, NAS of Ukraine, 2012 occurs in plastids, while the formation of additional double bonds may occur in both plastids and endoplasmatic reticulum. However, some reports demonstrate the cloning of genes, encoding $\Delta 9$-acyl-lipid desaturases, which supposedly function outside plastids [2].

The application of biotechnological approaches allows the obtaining of plants with the increased content of mono- and polyunsaturated fatty acids in the membrane lipids. The Agrobacterium tumefaciensmediated transformation resulted in the introduction of the gene coding for $\Delta 9$-acyl-lipid desaturase of cyanobacterium Anacystic nidulans into the Nicotiana tabacum L. genome. This enzyme catalyzes the formation of cys-double bond in position $\Delta 9$ in both $16-$ and 
18-carbon saturated fatty acids. Due to this fact the created plants have considerably increased number of unsaturated fatty acids in the majority of membrane lipids which leads to significant enhancement of cold tolerance [2]. Similar changes in cold tolerance were observed in tobacco plants, obtained via direct (using polyethylene glycol) transformation of protoplasts using vectors, containing either cDNA of $\triangle 9$-desaturases of cyanobacterium A. nidulans or cDNA of $\Delta 9$-desaturase of cold-resistant potato strain Solanum commersonii [3]. The introduction of heterologous desaturases of various origin results in comparable increase of cold tolerance. The expression of $\Delta 9$-desaturase of cyanobacterium S. vulcanus [4] and FAD7 desaturase of Arabidopsis thaliana L. [5] in tobacco leaves also allows the transformants to endure considerable cold stress. The potato plants of Solanum tuberosum L. become more resistant to low temperatures after the introduction of $\Delta 12$-desaturase gene of Synechocystis sp. PCC 6803 [6], as well as the gene of $\Delta 9$-desaturase of wild potato S. commersonii [7].

The data on an impact of stress factors on avocado fruit demonstrate that the increase in the activity of $\Delta 9$ desaturase (AvFAD9) resulted in higher resistance to the pathogen fungus Colletotrichum gloeosporioides [8].

Brassica napus L. is the third among the most important oil-bearing crops in the world (after palm and soya, faostat.fao.org/site/567/default.aspx\#ancor) by the amount of yielded oil. The selection of Brassica napus $\mathrm{L}$. is aimed first of all at the increase in the yield, oil-bearing, and the improvement of oil quality. This may be achieved also by obtaining plants, resistant to phytopathogenic fungi and with increased cold tolerance.

This work was aimed at canola plants, resistant to Roundup herbicide, which express the desaturase DesC of cyanobacterium S. vulcanus (without the signal of transporting into plastids) as a part of the bifunctional reporter gene for further testing of transgene lines for resistance to stress factors of different origin.

Materials and Methods. Plant material. Aseptically cultivated spring canola plants, Obreey cultivar, were used as material for transformation. The seeds were kindly provided by N. V. Slisarchuk (National
Scientific Center "Institute for Soil Science and Agrochemical Research", UAAS).

Genetic transformation was performed using leaf explants in accordance to the method, previously suggested by us [9]. The transformation was performed simultaneously with two vectors, each of them was cloned in A. tumefaciens, GV3101 strain. Vector $p B I S N$-desC $: \because l i c B M 3$ contains genes $\operatorname{des} C$ ( $\triangle 9$-desaturase) of cyanobacterium $S$. vulcanus and licBM3 (thermostable lichenase) of Clostridium thermocellum [10], fused in one reading frame under the control of $35 \mathrm{~S}$ promoter of cauliflower mosaic virus, and the selective gene of neomycinphosphotransferase II (nptII) under the control of nos promoter. Vector $p C B 133$ carries genes epsps (target) under the control of $35 \mathrm{~S}$ promoter of cauliflower mosaic virus and bar (selective) under the control of nos promoter. The regenerants were selected on the media with phosphinotricin (PPT, $5 \mathrm{mg} / \mathrm{l}$ ).

PCR-analysis. The total DNA was isolated from the leaf tissue of the transformed plants using the method [11]. The reaction was performed with $40 \mathrm{ng}$ of plant DNA as well as the corresponding primers in the concentration of $0.5 \mu \mathrm{M}$ and nucleoside triphosphates $500 \mu \mathrm{M}, 1$ unit of Taq DNA-polymerase, the reaction buffer contained $50 \mathrm{mM} \mathrm{KCl}, 10 \mathrm{mM}$ tris- $\mathrm{HCl}(\mathrm{pH} \mathrm{9}$, $25^{\circ} \mathrm{C}$ ), $0.1 \%$ triton $\mathrm{X}-100$ and $2 \mathrm{mM} \mathrm{MgCl}$. The total volume of the mixture was $20 \mu \mathrm{l}$. The gene epsps was identified using the primers, amplifying the fragment of 498 b.p. [12]. During multiplex PCR the genes desC and licBM3 were determined using the primers, amplifying fragments of 949 and 642 b.p. respectively [13]. DNA, isolated from the non-transformed plants (negative control) and $1 \mathrm{ng}$ of plasmid vector (positive control) were amplified with the same primers and in the same conditions using the Mastercycler personal thermocycler (Eppendorf, Germany). The parameters of amplification reaction corresponded to $[12,13]$. The PCR products were analyzed by electrophoresis in $1 \%$ agarose gel in tris-acetate buffer.

The isolation of the total RNA and RT-PCR was performed according to [14].

Testing for resistance to glyphosate. The sterile solution of N-phosphonomethylglycin $(2.5 \mathrm{mg} / \mathrm{l})$ was added to the hormone-free nutrient medium MS [15] after autoclaving to test the resistance in vitro. The root 
formation and general state of plants were estimated three weeks later. Three-week-old adapted plants were sprayed with Uragan Forter 500 SL herbicide under cover following the manufacturer's recommendations (Syngenta, Switzerland). The working solution contained $2.5 \mathrm{mg} / \mathrm{l}$ of glyphosate. The impact of the preparation was estimated 7 days later.

The qualitative evaluation of the thermostable lichenase activity was performed according to [13].

The quantitative evaluation of the thermostable lichenase activity was performed according to the modified method [16], estimating the concentration of free reducing sugars after the reaction of total protein extracts of the leaf tissue with lichenan. The leaves were ground in a singlefold volume of $100 \mathrm{mM}$ tris- $\mathrm{HCl}$ buffer ( $\mathrm{pH} 8.0$ ), containing $0.1 \mathrm{M} \mathrm{NaCl}, 5 \mathrm{mM} \mathrm{Na}_{2}$ EDTA and $10 \mathrm{mM}$ mercaptoethanol, and centrifuged at $13,000 \mathrm{~g}\left(4^{\circ} \mathrm{C}\right)$ for $5 \mathrm{~min}$. The supernatant $(20 \mu \mathrm{l})$ was added to $50 \mu 1$ of $0.5 \%$ aqueous solution of lichenan, diluted with water to $500 \mu 1$ and incubated at the temperature of $65-70{ }^{\circ} \mathrm{C}$ for $95 \mathrm{~min}$. Then we introduced $500 \mu 1$ of DNS-reagent (1\% dinitrosalicylic acid and $0.05 \%$ sodium sulfite in $1 \%$ sodium hydroxide solution), $165 \mu 1$ of $40 \% \mathrm{~K}-\mathrm{Na}$-tartrate and kept the mixture in the water bath at $95-100{ }^{\circ} \mathrm{C}$ for $10 \mathrm{~min}$, cooled till $4{ }^{\circ} \mathrm{C}$, and kept for $15-20 \mathrm{~min}$ at room temperature.

The optic density of solutions was measured at 510 $\mathrm{nm}$ using BioPhotometer (Eppendorf, v.1.35).

The concentration of reducing sugars was evaluated using the calibration chart for glucose. The activity of the enzyme, forming $1 \mu \mathrm{mol}$ of reducing sugars per $1 \mathrm{~s}$, was accepted as a unit of activity. The specific activity was evaluated per protein amount.

The determination of total soluble protein was performed using Bradford's method [17].

Results and Discussion. Three lines of canola plants on the basis of Obreey cultivar with selective genes nptII and bar, and target genes epsps and desC::licBM3, were obtained by simultaneous cocultivation of canola explants with two agrobacterial vectors ( $p C B 133$ and $p B I S N d e s C::$ licBM3).

Gene $n p t I I$, conferring the resistance to kanamycin, was selective in the construction $p B I S N$-desC : :licBM3. It is known that a number of difficulties arise at the regeneration stage in the process of using kanamycin with Cruciferae plants. Low doses of this antibiotic promote the occurrence of false transformants, which perish under selective pressure during the subsequent cultivation. High amounts of kanamycin hinder the very process of regeneration [18]. The solution may be found in temporary removal of selective pressure which prolongs the process of obtaining transformants. The aim of experiments with transgene lines with two target genes was to obtain the plants with $\operatorname{des} C$ gene as a part of the hybrid gene and simultaneous avoiding the negative impact of kanamycin.

It was previously demonstrated that the PPT presence increases the number of canola regenerants during the direct transformation of protoplasts using polyethylene glycol [19]. The selection on the media with PPT was successfully performed by us previously for obtaining transgene canola plants with the promoter-free bar gene [9], the gene of animal cytochrome [20], and the gene of human interferon alpha $2 b$ [21]. Therefore, in these experiments we also used the vector with T-DNA containing bar gene for the purpose of selecting transformed plants on the media with PPT.

17 canola lines were selected after the regeneration in selective conditions. The data of PCR-analysis demonstrated the presence of introduced target genes (epsps, desC::licBM3) in the nuclear genome of three of them - Bn18a, Bn18b, Bn18c (Fig. 1, $a, c$ ). The remaining lines are characterized by the presence of two heterologous genes from $p C B 133$ vector - epsps and bar. The combined integration of two T-DNA was observed with the frequency of $17.6 \%$. The simultaneous introduction of two and three T-DNA (with the frequency of 30 and $9.5 \%$, respectively) was observed in the experiments with A. thaliana with simultaneous transformation of plants using three vectors with different genetic constructions [22]. The plants with two target genes, introduced by different vectors, were obtained in the work with canola [23]. The experiments on introducing different genes in one or several constructions are performed to study and change metabolic pathways, to obtain composite proteins or protein complexes, and to investigate genetic control and regulation [24]. We used this approach in our work on the creation of transgene plants with the planned target genes for selection using the most suitable for canola selective agent phosphinotricin. 


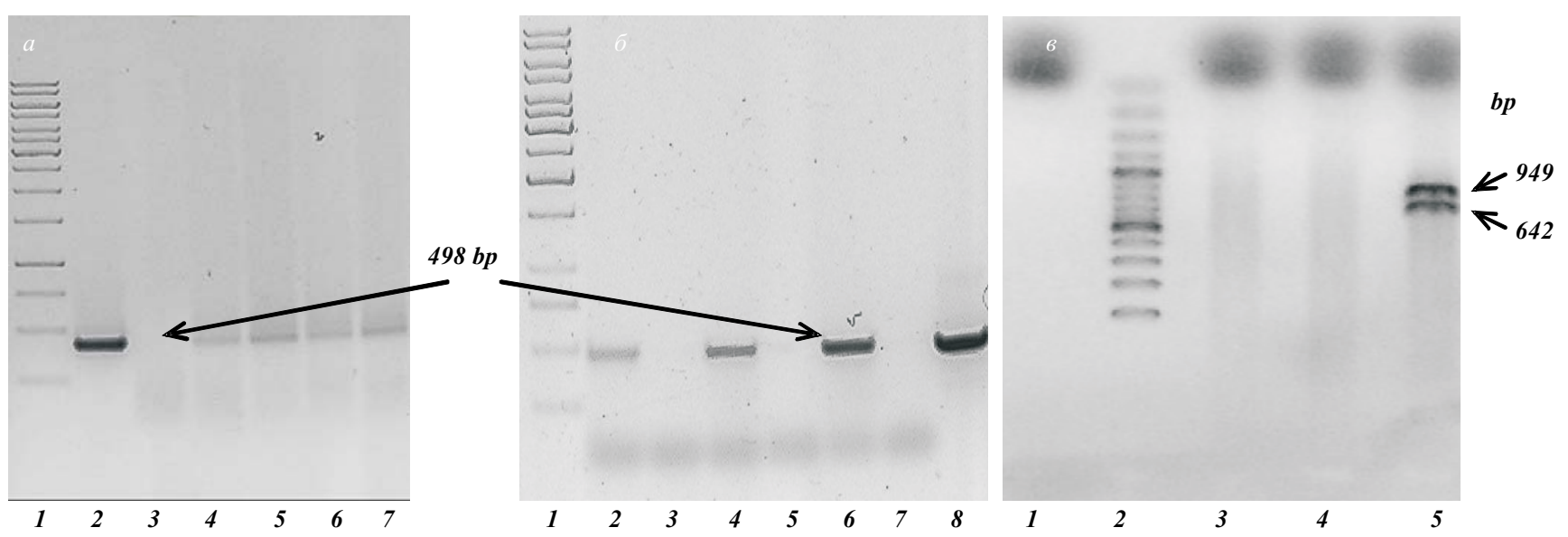

Fig. 1 The results of PCR, confirming the presence in transformed canola plants of sequences of epsps gene ( $a$ : 1 - molecular weight marker; 2 DNA of $p C B 133$ vector; 3 - negative control, DNA of the initial plant; 4-7-DNA of lines Bn18a, Bn18b, Bn18c and 18/133/7), desC and licBM3 genes ( $c$ : 1 - negative control, without DNA; 2 - molecular weight marker O'Gene-Ruler 100 bp DNA Ladder Plus, Fermentas, Lithuania; 3 negative control, DNA of the initial canola plant, Obreey cultivar; 4 - negative control, DNA of transgenic canola with cyp $11 A$ lgene, line Bn12/93/2; 5 - DNA of line Bn18a with desC: :licBM3 gene) [in transformed canola plants], as well as RT-PCR of transgenic canola plants ( $b: 1-$ molecular weight marker; 8 - DNA of $p C B 133$ vector, positive control; 3, 5, 7-amplification products after the synthesis of the first DNA strand on mRNA matrix of lines Bn18a, Bn18b and Bn18c without the revertase (negative control); 2, 4, 6 - amplification products after the synthesis of the first DNA strand with the addition of revertase of lines Bn18a, Bn18b and Bn18c

Further molecular and biological, biochemical and genetic investigations we performed, analyzing the plant lines with four introduced genes.

The expression of epsps gene in canola plants was demonstrated at the level of transcription (Fig. 1, c). In addition, it was tested in vitro while cultivating on the medium with N-phosphonomethyl glycine $(2.5 \mathrm{mg} / \mathrm{l})$ and during herbicide treatment in the greenhouse.

The plants of all three lines grew normally in vitro, remaining green and capable of root formation without any additional stimulation on a selective medium with glyphosate (Fig. 2,a). The control non-transformed plants were getting yellow and formed neither new leaves nor roots.

In the greenhouse conditions the transformants withstood spraying with the working solution of glyphosate while control plants withered and were not capable of further growth (Fig. 2, $b$ ).

The lichenase plate test (Fig. 3) was positive for all the three lines which proves the expression of the hybrid desC: :licBM3 gene.

The initial transformants $(\mathrm{Bn} 18 \mathrm{a}, \mathrm{Bn} 18 \mathrm{~b})$ were planted in the greenhouse, where they adapted easily, flowered and gave viable seeds by self-pollination. The obtained seeds were cultivated in aseptic conditions on the media with PPT $(10 \mathrm{mg} / \mathrm{l})$. No segregation by [the] resistance to phosphinotricin was observed which indicates the integration of more than one copy of bar transgene. The selected PPT-resistant seedlings were passaged on the medium with kanamycin. The seedlings, resistant to both kanamycin and PPT, were tested for the lichenase activity (Fig. 3).

The quantitative evaluation of the enzyme activity demonstrated its absence in the control plants, while its level varied among the transgene lines (Table). Line $18 \mathrm{~b}$ was remarkable for the highest lichenase activity. Lines $18 \mathrm{a}$ and 18b/25 were characterized by comparable, but considerably lower activity levels, compared to line $18 \mathrm{~b}$ (by $\sim 40 \%$ ). The lichenase activity for line $18 \mathrm{a} / 2$ appeared to be lower than the detection level. The initial transformants (18b and 18a) had higher lichenase activity compared to the first generation plants, obtained by self-pollination of the initial lines $(18 \mathrm{~b} / 25,18 \mathrm{a} / 2,18 \mathrm{a} / \mathrm{b})$.

A diverse level of the lichenase activity in the transgene canola lines indicates analogous differences in the expression of the target gene of $\Delta 9$-desaturase as a part of the hybrid gene. The level of gene expression may depend on the integration locus of the foreign DNA and the number of integrated transgene copies. The similar results, reflecting evaluation of the target gene expression by determination of the lichenase 

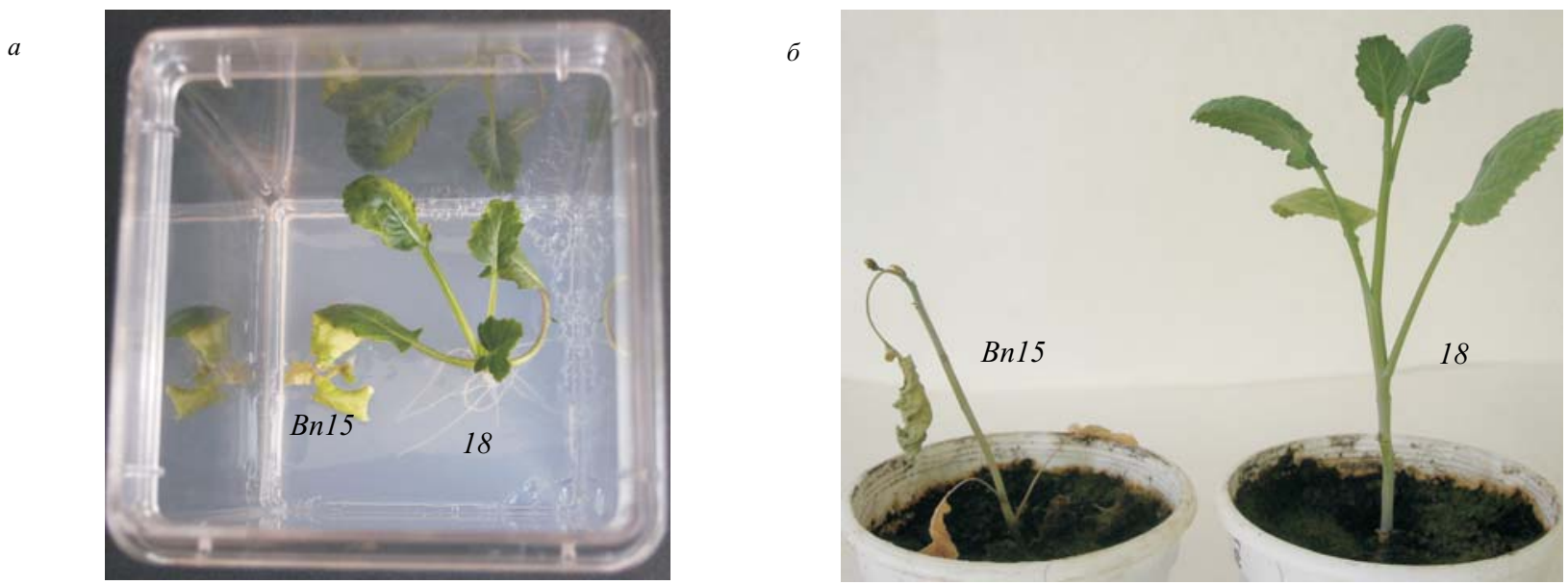

Fig. 2 Testing glyphosate resistance: $a$ - two-week-old plants of the initial Obreey cultivar (Bn18) and line 18a in vitro on hormone-free agarised MS medium with N-phosphonomethyl glycine $(2.5 \mathrm{mg} / \mathrm{l})$; b - three-week-old plants of Obreey cultivar (Bn18) and transgenic line $18 \mathrm{a}$ after the treatment with herbicide Uragan Forte 500 SL in the greenhouse

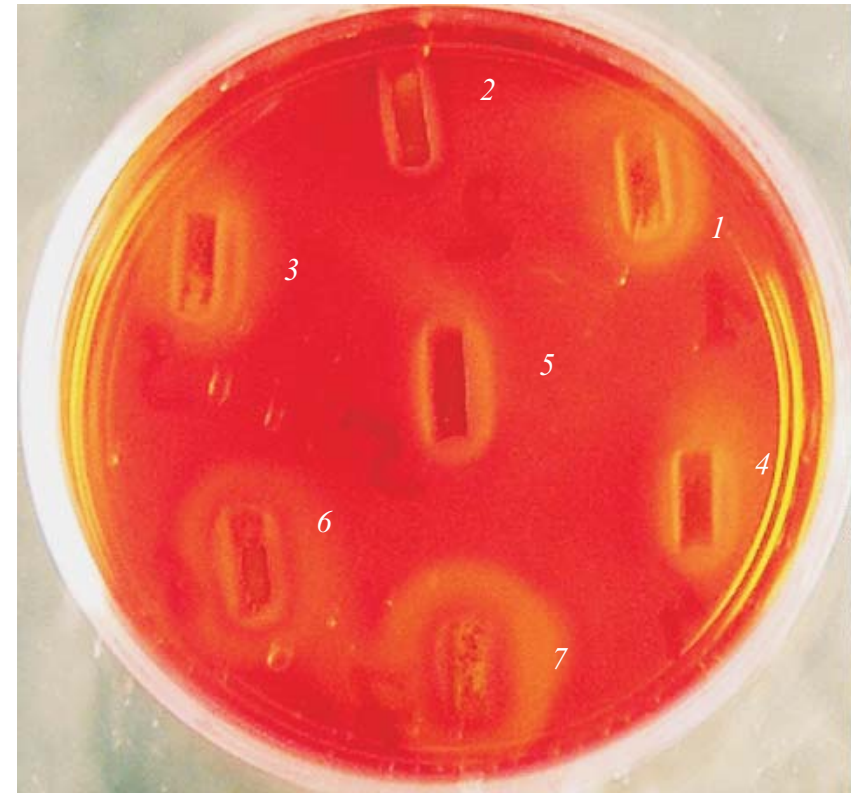

Fig. 3 Qualitative determination of the activity of thermostable lichenase in canola plants with $\operatorname{des} C: \because l i c B M 3$ gene. Into the wells in agarized medium, containing lichenan, were introduced the extracts of lines : $1-18 \mathrm{~b} ; 2$ - initial Obreey cultivar (Bn18);3-18a;4-18a/6;5$18 \mathrm{a} / 2 ; 6-18 \mathrm{~b} / 25 ; 7$ - tobacco lines expressing desC::licBM3 gene (positive control)

activity in the hybrid protein, were obtained by the method of zymograms of protein extracts of potato plants, transformed by cry $3 a M:: l i c B M 2$ gene for protection from Colorado beetle [25]. Different activity levels of lichenase in the hybrid DesA-LicBM3 protein
The lichenase activity in canola plants with licBM3 gene of the thermostable lichenase of Clostridium thermocellum

\begin{tabular}{c|c|c|c}
\hline Line & $\begin{array}{c}\text { Lichenase } \\
\text { activity (pour } \\
\text { plate test) }\end{array}$ & $\begin{array}{c}\text { Resistance to } \\
\text { kanamycin }\end{array}$ & $\begin{array}{c}\text { Lichenase activity, } \mu \mathrm{M} \\
\text { of glucose } 10^{-6} /(\mu \mathrm{g} \text { of } \\
\text { protein) }\end{array}$ \\
\hline $18 \mathrm{~b}$ & + & + & 9,28 \\
$\begin{array}{c}\text { Bn18 } \\
(\text { control })\end{array}$ & - & - & Not detected \\
$18 \mathrm{a}$ & + & + & 5,52 \\
$18 \mathrm{a} / 6$ & +- & + & 2,64 \\
$18 \mathrm{a} / 2$ & +- & + & Not detected \\
$18 \mathrm{~b} / 25$ & + & + & 5,02 \\
\hline
\end{tabular}

were also registered in the potato plants with the increased lipid content in the leaves and elevated amount of unsaturated fatty acids in the membrane lipids [6].

Conclusions. Therefore, the simultaneous introduction of four genes in two independent vectors allowed us to obtain the plants with functional heterologous genes. The expression of epsps gene was demonstrated at the transcription level, in vitro and in vivo (greenhouse). The determination of the licBM3 gene product activity as a part of the hybrid protein permitted to evaluate the expression of desaturase gene, fused with it. The inheritance of the introduced 
genes and their expression in the first generation were revealed.

Acknowledgments. The work was supported with the grant of NAS of Ukraine UkrINTEI No. 0110U 006062, grant of GFFDRFFD F40.4/021 and grant of RFFR No. 11-04-90466Ukr_f_a.

Л. А. Сахно ${ }^{1}$, И. М. Герасименко ${ }^{I}$, И. К. Комарниикий ${ }^{1}$ Ю. В. Шелудько , И. В. Голденкова-Павлова ${ }^{2}$

Создание устойчивых к глифосату растений

Brassica napus L., экспрессирующих десатуразу

DesC цианобактерии Synechococcus vulcanus

${ }^{1}$ Институт клеточной биологии и генетической инженерии НАН Украины

Ул. Академика Заболотного, 148, Киев, Украина, 03680

${ }^{2}$ Институт общей генетики им. Н. И. Вавилова РАН

Ул. Губкина, 3, Москва, Российская Федерация, 119991

Резюме

Цель. Создание растений рапса, устойчивых к глифосату и экспрессирующих бифункциональный гибридный ген $\operatorname{des} C:: l i c B M 3$, в котором последовательность десатуразы DesC иианобактерии S. vulcanus без сигнала транспорта в пластиды слита с последовательностью гена репортерного белка термо- стабильной лихеназы LicB Clostridium thermocellum. Методы. Agrobacterium tumefaciens-опосредованная трансформация, ПЦР, качественное и количественное определение активности термостабильной лихеназы, генетический анализ. Результаты. Получены трансгенные растения рапса, несущие два целевых гена: енолпируватшикиматфосфатсинтазы (ерsps), обеспечивающего устойчивость растений к гербииидам на основе фосфонометилгличина, и гена desC::licBM3. Присутствие трансгенов в геноме растений доказано методом мультиплексной ПЦР. Экспрессия гена ерsps показана на уровне транскрипции, в условияx in vitro u in vivo (теплица). Наличие продукта гена licBM3 6 составе гибридного белка позволило оценить экспрессию слитого с ним гена десатуразы. Прослежено наследование введенных генов и их экспрессия в первом поколении. Выводы. Получены линии трансгенных растений рапса, подтверждено присутствие трансгенов в геноме растений и доказана экспрессия целевых генов.

Ключевые слова: Brassica napus, epsps, desC, licBM3, лихена$3 a$.

Л. О. Сахно, І. М. Герасименко, І. К. Комарницький, Ю. В. Шелудько, І. В. Голденкова-Павлова

Створення стійких до гліфосату рослин Brassica napus

L., які експресують десатуразу DesC ціанобактерії

Synechococcus vulcanus

Резюме

Meта. Створення стійких до гербіциду Rоundир рослин ріпаку, що експресують біфункиіональний гібридний ген $\operatorname{des} C: \because l i c B M 3$, в якому послідовність десатурази DesC иіанобактерії $S$. vulcanus без сигналу транспорту в пластиди злита з послідовністю гена репортерного білка ліхенази LicBM3 Clostridium thermocellum. Meтоди. Agrobacterium tuтеfaciens-опосередкована трансформація, ПЛР, якісне і кількісне визначення активності термостабільної ліхенази, генетичний аналіз. Результати. Отримано трансгенні рослини ріпаку, які несуть два иільових гени: єнолпіруватшикіматфосфатсинтази (ерsps), щя забезпечує стійкість рослин до гербіцидів на основі фосфонометилглічину, і гена $\operatorname{des} C:: l i c B M 3$. Присутність трансгенів у геномі рослин підтверджено методом мультиплексної ПЛР. Експресію гена ерsрs показано на рівні транскрипиіi, за умов in vitro та in vivo (тепличя). Наявність продукту гена ІісВМЗ у складі гібридного білка дозволила оцінити експресію злитого з ним гена десатурази. Простежено успадкування введених генів і їхня експресія в першому поколінні. Висновки. Отримано лінії трансгенних рослин ріпаку, підтверджено присутність трансгенів у геномі рослин і доведено експресію цілььвих генів.

Ключові слова: Brassica napus, epsps, desC, licBM3, ліхеназа.

\section{REFERENCES}

1. Los D. A., Murata N. Structure and expression of fatty acid desaturases// Biochim. Biophys. Acta.-1998.-1394, N 1.-P. 3-15.

2. Ishizaki-Nishizawa O., Fujii T., Azuma M., Sekiguchi K., Murata N., Ohtani T., Toguri T. Low-temperature resistance of higher plants is significantly enchanced by a nonspecific cyanobacterial desaturase// Nat. Biotechnol.-1996.-14, N 8.-P. 1003-1006.

3. Craig W., Lenzi P., Scotti N., De Palma M., Saggese P., Carbone V., McGrath Curran N., Magee A. M., Medgyesy P., Kavanagh T. A., Dix P. J., Grillo S., Cardi T. Transplastomic tobacco plants expressing a fatty acid desaturase gene exhibit altered fatty acid profiles and improved cold tolerance// Transgenic Res.-2008.17, N 5.-P. 769-782.

4. Orlova I. V., Serebriiskaya T. S., Popov V., Merkulova N., Nosov A. M., Trunova T. I., Tsydendambaev V. D., Los D. A. Transformation of tobacco with a gene for the thermophilic acyl-lipid desaturase enhances the chilling tolerance of plants // Plant Cell Physiol.-2003.-44, N 4.-P. 447-450.

5. Kodama H., Hamada T., Horiguchi C., Nishimura M., Iba K. Genetic enhancement of cold tolerance by expression of a gene for chloroplast $\omega-3$ fatty acid desaturase in transgenic tobacco // Plant Physiol.-1994.-105, N 2.-P. 601-605.

6. Maali A. R., Goldenkova-Pavlova I. V., Pchelkin V. P., Tsydendambaev V. D., Los D. A., Nosov A. M. Acyl-lipid $\Delta 12$-desaturase of the cyanobacterium increases the unsaturation degree in transgenic potato (Solanum tuberosum L.) // Biologija.-2007.-53, N 2.P. 4-7.

7. De Palma M., Grillo S., Massarelli I., Costa A., Balogh G., Vigh L., Leone A. Regulation of desaturase gene expression, changes in membrane lipid composition and freezing tolerance in potato plants // Mol. Breeding.-2008.-21, N 1.-P. 15-26.

8. Madi L., Wang X., Kobiler I., Lichter A., Prusky D. Stress on avocado fruits regulates $\Delta^{9}$-stearoyl ACP desaturase expression, fatty acid composition, antifungal diene level and resistance to $\mathrm{Col}$ letotrichum gloeosporioides attack // Physiol. Mol. Plant Pathol.2003.-62, N 5.-P. 277-283.

9. Sakhno L. A., Gocheva E. A., Komarnitskii I. K., Kuchuk N. V. Stable expression of the promoterless bar gene in transformed rapeseed plants // Cytology and Genetics.-2008.-42, N 1.-P. 21-28.

10. Maali R., Schimschilaschvili H. R., Pchelkin V. P., Tsydendambaev V. D., Nosov A. M., Los D. A., Goldenkova-Pavlova I. V. Comparative expression in Escherichia coli of the native and 
hybrid genes for acyl-lipid $\Delta 9$ desaturase // Rus. J. Genet.-2007.43, N 2.-P. 121-126.

11. Cheung W. Y., Hubert N., Landry B. S. A simple and rapid DNA microextraction method for plant, animal and insect suitable for RAPD and other PCR analyses // PCR Methods Appl.-1993.-3, N 1.-P. 69-70.

12. Sakhno L. O., Komarnitskii I. K., Maistrov P. D., Kuchuk M. V. Creation of glyphosate resistant canola by synthetic epsps gene introduction // Factors of experimental evolution of organisms.Kyiv: Logos, 2011.-P. 388-393.

13. Gerasymenko I. M., Sakhno L. O., Golovach I. S., Kishchenko O. M., Sindarovska Y. R., Shimshilashvili H. R., Sheludko Y. V., Goldenkova-Pavlova I. $V$. Raise of plants possessing genes for acyl-lipid desaturases from the cyanobacteria // VOGiS Herald.2010.-14, N 1.-P. 127-133.

14. Logemann J., Schell J., Willmitzer L. Improved method for the isolation of RNA from plant tissues // Anal. Biochem.-1987.163, N 1.-P. 16-20.

15. Murashige T., Skoog F. A revised medium for rapid growth and bioassays with tobacco tissue cultures // Physiol. Plant.-1962.15, N 3.-P. 473-497.

16. Wood T. M., Bhat K. M. Methods for measuring cellulase activities // Methods Enzymol.-1988.-160.-P. 87-112.

17. Bradford M. M. A rapid and sensitive method for the quantitation of microgram quantities of protein utilizing the principle of protein-dye binding // Anal. Biochem.-1976.-72.-P. 248-254.

18. Radchuk V. V., Klocke E., Radchuk R. I., Blum Ya. B. Production of transgenic rape plants (Brassica napus L.) using Agrobacterium tumefaciens // Rus. J. Genet.-2000.-36, N 7.-P. 932-941.

19. Herve C., Rouan D., Guerche P., Montane M.-H., Yot P. Molecular analysis of transgenic rapeseed plants obtained by direct transfer of two separate plasmids containing, respectively, the cauliflower mosaic virus coat protein gene and a selectable marker gene // Plant Science.-1993.-91, N 2.-P. 181-193.

20. Sakhno L. O., Morgun B. V., Kvasko O. Y., Kuchuk M. V. Transformed canola plants expressing mammalian cyp $11 A 1$ gene of cytochrome P450scc // Biotechnology (Ukrainian).-2010.-3, N 5.-P. 74-82.

21. Sakhno L. O., Kvasko O. Y., Olevinska Z. M., Spivak M. Y., Kuchuk $M$. V. Creation of transgenic Brassica napus L. plants expressing human alpha $2 \mathrm{~b}$ interferon gene // Cytology and Genetics.-2012.46, N 6.-P. 342-346.

22. Radchuk V. V., Van D. T., Klocke E. Multiple gene co-integration in Arabidopsis thaliana predominantly occurs in the same genetic locus after simultaneous in planta transformation with distinct Agrobacterium tumefaciens strains // Plant Science.2005.- 168, N 6.-P. 1515-1523.

23. De Block M., Debrouwer D. Two T-DNA's co-transformed into Brassica napus by a double Agrobacterium tumefaciens infection are mainly integrated at the same locus // Theor. Appl. Genet.-1991.-82, N 3.-P. 257-263.

24. Naqvi S., Farre G., Sanahuja G., Capell T., Zhu C., Christou P. When more is better: multigene engineering in plants // Trends Plant Sci.-2010.-15, N 1.-P. 48-56.

25. Goldenkova-Pavlova I. V., Mirahorli N., Maali A. R., Isaenko E., Kartel N. A. Experimental models for creation of transgenic plants resistant to stressors // Cytology and Genetics.-2007.-41, N 3.-P. 167-171. 